University of Nebraska - Lincoln

DigitalCommons@University of Nebraska - Lincoln

\title{
NUTRIENT ACCUMULATION AND PHOTOSYNTHESIS IN GLYPHOSATE-RESISTANT SOYBEANS IS REDUCED UNDER GLYPHOSATE USE
}

\author{
Luiz Henrique Saes Zobiole \\ State University of Maringá, Ihzobiole@uol.com.br \\ Rubem Silvério de Oliveira Jr. \\ State University of Maringá \\ Robert John Kremer \\ United States Department of Agriculture \\ Antonio Saraiva Muniz \\ State University of Maringá \\ Adilson de Oliveira Jr. \\ Embrapa Soybean
}

Follow this and additional works at: https://digitalcommons.unl.edu/usdaarsfacpub

Part of the Agricultural Science Commons

Saes Zobiole, Luiz Henrique; de Oliveira, Rubem Silvério Jr.; Kremer, Robert John; Muniz, Antonio Saraiva; and de Oliveira, Adilson Jr., "NUTRIENT ACCUMULATION AND PHOTOSYNTHESIS IN GLYPHOSATERESISTANT SOYBEANS IS REDUCED UNDER GLYPHOSATE USE" (2010). Publications from USDA-ARS / UNL Faculty. 551.

https://digitalcommons.unl.edu/usdaarsfacpub/551

This Article is brought to you for free and open access by the U.S. Department of Agriculture: Agricultural Research Service, Lincoln, Nebraska at DigitalCommons@University of Nebraska - Lincoln. It has been accepted for inclusion in Publications from USDA-ARS / UNL Faculty by an authorized administrator of DigitalCommons@University of Nebraska - Lincoln. 


\title{
NUTRIENT ACCUMULATION AND PHOTOSYNTHESIS IN GLYPHOSATE-RESISTANT SOYBEANS IS REDUCED UNDER GLYPHOSATE USE
}

\author{
Luiz Henrique Saes Zobiole, ${ }^{1}$ Rubem Silvério de Oliveira Junior, ${ }^{1}$ \\ Robert John Kremer, ${ }^{2}$ Antonio Saraiva Muniz, ${ }^{3}$ \\ and Adilson de Oliveira Junior ${ }^{4}$ \\ ${ }^{1}$ Center for Advanced Studies in Weed Science (NAPD), State University of Maringá, \\ Maringá, Brazil \\ ${ }^{2}$ United States Department of Agriculture, Agricultural Research Service, Cropping Systems \\ and Water Quality Research Unit, Columbia, Missouri, USA \\ ${ }^{3}$ Agronomy Department, State University of Maringá, Maringá, Brazil \\ ${ }^{4}$ Embrapa Soybean, Londrina, Brazil
}

\begin{abstract}
口 Global production of glyphosate-resistant (GR) soybean [Glycine max (L.) Merr.] continues to increase annually; however, there are no particular specific fertilizer recommendations for the transgenic varieties used in this system largely because reports of glyphosate effects on mineral nutrition of GR soybeans are lacking. Several metabolites or degradation products of glyphosate have been identified or postulated to cause undesirable effects on GR soybeans. In this work we used increasing glyphosate rates in different application on cv. 'BRS 242 GR' in order to evaluate photosynthetic parameters, macro- and micronutrient uptake and accumulation and shoot and root dry biomass production. Increasing glyphosate rates revealed a significant decrease in photosynthesis, macro and micronutrients accumulation in leaf tissues and also decreases in nutrient uptake. The reduced biomass in GR soybeans represents additive effects from the decreased photosynthetic parameters as well as lower availability of nutrients in tissues of the glyphosate treated plants.
\end{abstract}

Keywords: nutrient, photosynthesis, glyphosate, glyphosate-resistant soybean

\section{INTRODUCTION}

Glyphosate is used as foliar-applied herbicide with a wide spectrum of weed control. It is translocated throughout the plant continually through the phloem and accumulates in young leaves, roots, and meristems (Bromilow

Received 5 August 2009; accepted 9 November 2009.

Address correspondence to L. H. S. Zobiole, Center for Advanced Studies in Weed Science (NAPD), State University of Maringá, Colombo Av., 5790, 87020-900, Maringá, PR, Brazil. E-mail: lhzobiole@ uol.com.br 
et al., 1993). Glyphosate inhibits 5-enolpyruvylshikimate-3-phosphate synthase (EPSPS) in the shikimate pathway responsible for the biosynthesis of aromatic amino acids (Sprankle et al., 1975).

In glyphosate-resistant (GR) soybean, a small amount of glyphosate is bound to EPSPS and very little is degraded within the plant (Arregui et al., 2003) and most of the remaining herbicide is translocated to active metabolic sinks (Duke et al., 2003). Although transgenic soybean is resistant to glyphosate, application of glyphosate has resulted in significant soybean injury under certain conditions and with certain salt formulations of glyphosate (Reddy and Zablotowicz, 2003). The typical visual symptom noticed in the field after glyphosate application to GR soybeans is known as "yellow flashing" or yellowing of the upper leaves. Many farmers have noticed that some transgenic soybeans are sensitive to water stress; others have reported visual plant injury in some GR soybean varieties after glyphosate application (Zablotowicz and Reddy, 2007) and also the nutritional status of GR soybeans is strongly affected by glyphosate (Zobiole et al., 2010). Field observations in Brazil and the north central United States have reported that frequent applications of glyphosate induce iron (Fe), zinc ( $\mathrm{Zn})$, and manganese (Mn) deficiencies in GR- soybean (Franzen et al., 2003; Johal and Huber, 2009).

The first mode of action reported for glyphosate was as a metal chelator, and the molecule was initially patented for that purpose (Jaworski, 1972; Bromilow et al., 1993), therefore, it could be hypothesized that its application can exert negative side-effects on plant growth and nutritional status under some conditions, even in transgenic, GR soybean.

In fact, there are very few reports of glyphosate effects on mineral nutrition of GR soybeans. In the present research, an experiment was conducted under controlled conditions using nutrient solution, to study the effect of glyphosate on macro and micronutrient accumulation and uptake, photosynthetic parameters, shoot and root dry biomass and nutritional status in GR soybean cv. 'BRS 242 GR'.

\section{MATERIAL AND METHODS}

\section{Growth Conditions and Cultivation Practices}

The experiment was carried out in greenhouse equipped with an evaporative cooling system (25-35: $20-22^{\circ} \mathrm{C}$ day/night) under natural daylight conditions at the State University of Maringá, between 22 July and 20 September $2008\left(23^{\circ} 25^{\prime} \mathrm{S}, 51^{\circ} 57^{\prime} \mathrm{W}\right)$.

Seeds were sterilized for $2 \mathrm{~min}$ in $2 \%$ sodium hypochlorite $(\mathrm{NaClO})$ and placed in paper rolls (Germitest, CIAL, Paulínea, SP, Brazil) for germination. Seedlings with $5 \mathrm{~cm}$ root lengths, were transplanted into pots containing nutrient solution. Experimental units were polyethylene pots $\left(3.7 \mathrm{dm}^{3}\right)$ under 
constant aeration. For the first 10 days, the plants were grown in a complete nutrient solution (Hoagland and Arnon, 1950), diluted to 1/6 of the usual concentration; in the next two weeks solutions were supplied at $1 / 3$ strength; and thereafter returned to full-strength. Nutrient solutions were exchanged every 10 days and pots volume was replenished daily with distilled and deionized water. The $\mathrm{pH}$ of the solutions was maintained at $5.8 \pm 0.2$ by adjusting with sodium hydroxide $(\mathrm{NaOH})$ or hydrochloric acid $(\mathrm{HCl})$.

\section{Glyphosate Applications}

The pots were placed outside the greenhouse for application of the commercially formulated isopropylamine salt of glyphosate $\left(360 \mathrm{~g}\right.$ a.e. $\left.\mathrm{L}^{-1}\right)$, using a carbon dioxide $\left(\mathrm{CO}_{2}\right)$ pressurized backpack sprayer equipped with SF110.02 nozzles calibrated to deliver a spray volume of $190 \mathrm{~L} \mathrm{ha}^{-1}$ at a pressure of $2 \mathrm{~kg} \mathrm{~cm}^{-2}$. Environmental conditions during the applications included air temperature between 25 and $29^{\circ} \mathrm{C}$, relative humidity between 80 and $89 \%$, wind speed between 5 and $10 \mathrm{~km} \mathrm{~h}^{-1}$, and open sky with no clouds. After herbicide applications, the pots were returned to the greenhouse. The glyphosate solutions were not sprayed until run-off from leaves.

\section{Measurement of Response Variables}

All variable responses were measured when soybean plants reached R1 growth stage (58 DAE). Net photosynthesis (A) was evaluated using an infrared gas analyzer (IRGA: ADC model LCpro+, Analytical Development Co. Ltd, Hoddesdon, UK). Carboxylation efficiency was calculated as A/Ci. Evaluations were always carried out between 7:00 and 11:00 am, choosing the last fully expanded trifoliate (diagnostic leaf) of plants in each pot. The records were taken by automatic time-logging equipment with two measures of $3 \mathrm{~min}$ for each diagnostic leaf.

In the same diagnostic leaf, a portable chlorophyll fluorometer (OS-30, Opti-Sciences, Inc., Tyngsboro, MA, USA) was used in pulse modulation to determine the chlorophyll fluorescence in plants under steady state conditions (Fo) and maximal fluorescence under steady state conditions (Fm).

During the evaluations at R1 stage, the chlorophyll content was also measured using a SPAD meter (SPAD-502, Minolta, Ramsey, NJ, USA). The meter measures absorption at 650 and $940 \mathrm{~nm}$ wavelengths to estimate chlorophyll levels (Singh et al., 2002; Richardson et al., 2002; Pinkard et al., 2006). SPAD readings were taken at the terminal leaflet of the diagnostic leaf. The SPAD sensor was placed randomly on leaf mesophyll tissue only, avoiding the veins. Two leaves were chosen per plant per pot and measurements were immediately taken per leaf and averaged to provide a single SPAD unit.

Just prior to collecting leaves at the R1 stage, $50 \mathrm{~mL}$ samples of nutrient solution were collected from each pot, in order to determine the 
nutrient concentrations and electrical conductivity. After these assessments were completed, the leaves of the upper par including the diagnostic leaf were collected from each pot. Leaves were washed in deionized water, packed in paper bags and dried in an air circulation oven at $65-70^{\circ} \mathrm{C}$ until constant weight, in order to determine their macro and micronutrient contents. The concentration of phosphorus $(\mathrm{P})$, potassium $(\mathrm{K})$, calcium $(\mathrm{Ca})$, magnesium $(\mathrm{Mg})$, sulfur $(\mathrm{S}), \mathrm{Zn}, \mathrm{Mn}$, and copper $(\mathrm{Cu})$ was obtained after complete perchloric nitric digestion and $\mathrm{B}$ concentration after dry digestion. All elements were measured using an AES Perkin Elmer inductively coupled plasma (ICP; Perkin Elmer, Wellesley, MA, USA) spectrometry. Nitrogen was determined by the Kjeldahl method (Baker and Thompson, 1992), after complete sulfuric digestion.

At harvest, plant height was taken. Shoot and root system were harvest, packed in paper bags and dried in air circulation oven at $65-70^{\circ} \mathrm{C}$ until constant weight, in order to determine the dry biomass.

\section{Experimental Design and Data Analysis}

Experimental units were distributed in a randomized blocks experimental design, with four replicates. Treatments were combined in a factorial scheme $(5 \times 2)+1$. The first factor was represented by five glyphosate doses (600, 900, 1200, 1800 and $2400 \mathrm{~g}$ a.e. ha ${ }^{-1}$ ) in a GR soybean (cv. 'BRS 242 GR'). The second factor was the two application manners (single or sequential application). The additional treatment was a non-applied treatment. The treatments under single applications were applied at V4 stage (24 days after emergence, DAE) and for sequential applications at V4 (24 DAE-50\% of dose) and V7 stage (36 DAE- $50 \%$ of dose).

Data errors passed through the test of Shapiro and Wilk (1965), to evaluate their normality. Equations were adjusted by SigmaPlot 10.0 (SPSS, Chicago, IL, USA) and SAS (SAS Institute, Cary, NC, USA).

\section{RESULTS AND DISCUSSION}

\section{Photosynthetic Parameters}

All photosynthetic parameters (A, SPAD, Fo, Fm) evaluated were reduced linearly as glyphosate rates increased, despite the application manner (Figure 1). Therefore, any glyphosate input may take soybean plants temporarily to suboptimal levels of A.

Before glyphosate applications (22 DAE) the photosynthetic rate (A) was between 10-11 $\mu \mathrm{mol} \mathrm{CO}_{2} \mathrm{~m}^{-2} \mathrm{~s}^{-1}$ (Figures $1 \mathrm{~A}$ and $1 \mathrm{~B}$ ). Procópio et al. (2004) found very similar values of $\mathrm{A}\left(11-12 \mu \mathrm{mol} \mathrm{CO}_{2} \mathrm{~m}^{-2} \mathrm{~s}^{-1}\right)$ at $39 \mathrm{DAE}$ for Glycine max and Phaseolus vulgaris, considered optimal for this vegetative phase (Liu et al., 2005). Decreases in photosynthetic rates are directly linked 

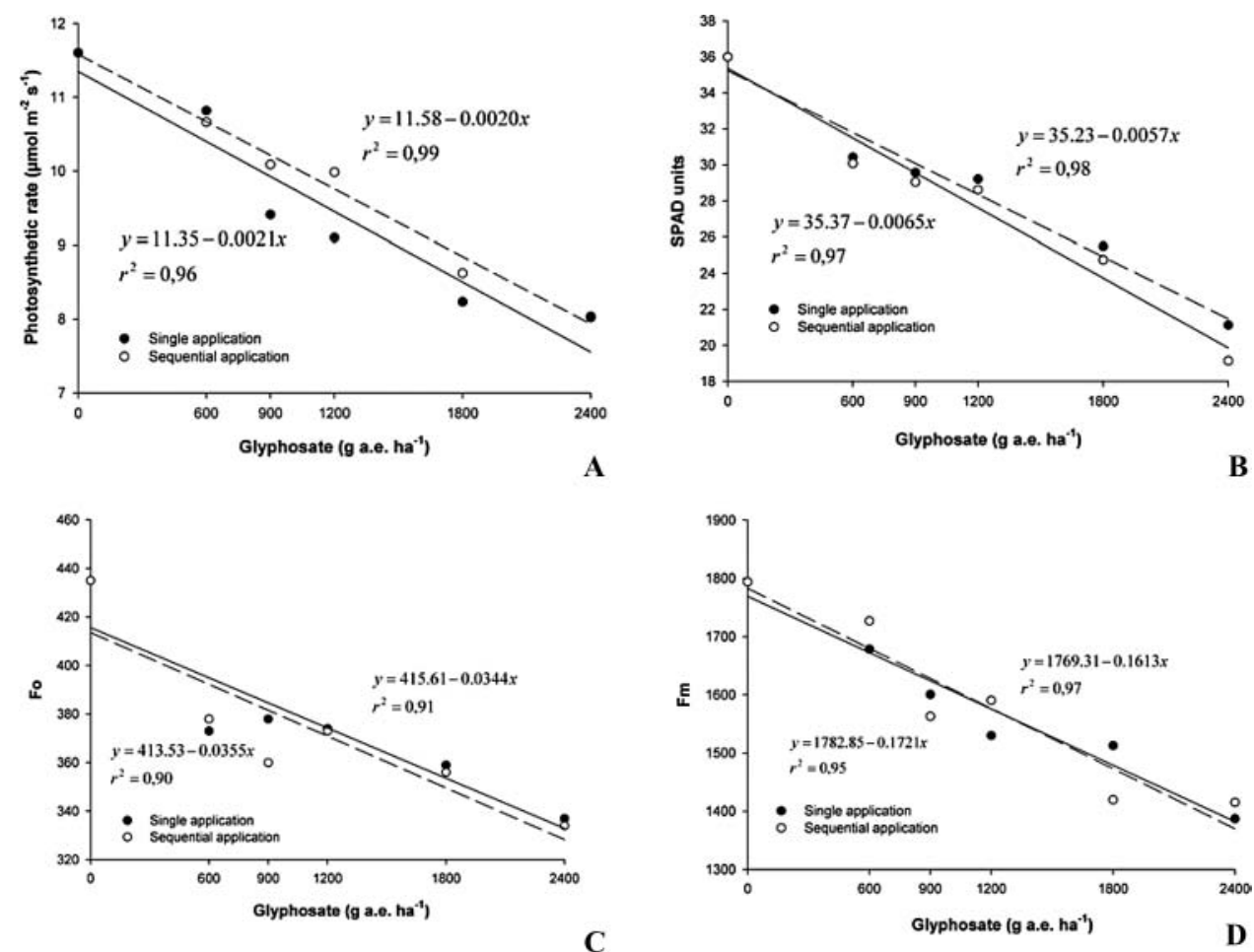

FIGURE 1 A) Photosynthetic rate, B) SPAD units, C) fluorescence (Fo) and D) maximal fluorescence (Fm), at R1 growth stage in GR soybean under increasing glyphosate doses in single (solid line) or sequential (dashed line) applications. Each point represents an average of four independent replicates.

to the effect of glyphosate rates on chlorophyll contents estimated by SPAD units, which, in turn may partly explain chlorosis symptoms observed in GR soybean plants after glyphosate application.

The glyphosate effects on photosynthetic parameters probably reflects lower chlorophyll content in glyphosate-treated plants (Figure 1B) as a result of direct damage to chlorophyll by glyphosate (Kitchen et al., 1981a, 1981b; Lee, 1981; Reddy et al., 2004) or immobilization of $\mathrm{Mg}$ and $\mathrm{Mn}$, nutrients required for chlorophyll production and function (Beale, 1978; Taiz and Zeiger, 1998). The main metabolite of glyphosate, AMPA, may also cause injury to GR-soybeans treated with glyphosate and contribute to chlorosis (Pline et al., 1999; Reddy et al., 2000; Duke et al., 2003; Reddy et al., 2004). Previous studies have demonstrated that photosynthetic parameters (Net photosynthesis, transpiration rate, stomatal conductance) were severely affected by glyphosate in the different maturity group cultivars evaluated of GR soybeans growing in different soil types (Zobiole et al., 2010).

Light energy can be used to drive photosynthesis, dissipated as heat, or re-emitted as light, the latter also known as the process of fluorescence (Lichtenthaler and Miehé, 1997; Maxwell and Johnson, 2000). Changes 
in fluorescence were observed in plants treated with herbicides that inhibit amino acid synthesis (Ireland et al., 1986) and the respiratory pathway (Gonzalez-Moro et al., 1997). The decrease in Fo and Fm was also proportional to glyphosate doses, although there was no difference between single or sequential application (Figures 1C and 1D). As chlorophyll fluorescence is a measure illustrating photosynthetic efficiency of the plants, and eventually productivity (Maxwell and Johnson, 2000), the data of Figure 1C and 1D suggest that glyphosate might reflect changes in the thylakoid membrane organization and function.

The reduction of photosynthetic parameters at R1 growth stage in GR soybeans by glyphosate doses, long after herbicide application, suggests that either glyphosate or its metabolites have long-term physiological impacts in soybean plants (Zobiole et al., 2010). Previous work (Arregui et al., 2003; Duke et al., 2003) has demonstrated that glyphosate can remain even further during the crop growth cycle, reaching the complete physiological maturity of plants.

\section{Nutrient Accumulation}

Macro and micronutrient accumulation was strongly reduced by increased doses of glyphosate (Figures 2 and 3). With the range of doses in this work, macronutrient accumulation was decreased from $46 \%$ ( $\mathrm{P}$ in sequential application) to $88 \%$ (Ca in single application). For either application manner the glyphosate doses affect macronutrient accumulation in the following order: $\mathrm{Ca}>\mathrm{Mg}>$ nitrogen $(\mathrm{N})>\mathrm{S}>\mathrm{K}>\mathrm{P}$. For micronutrient depletion, decreases, ranged from $58 \%$ (B in sequential application) to $99 \%$ (Fe in single application). However there was a differential response for application manner, in which a single application of glyphosate affected the micronutrient accumulation in the following order: $\mathrm{Fe}>\mathrm{Mn}>$ cobalt $(\mathrm{Co})>\mathrm{Zn}>\mathrm{Cu}>$ boron $(\mathrm{B})>$ molybdenum $(\mathrm{Mo})$; and for sequential application the order of decrease was $\mathrm{Fe}>\mathrm{Co}>\mathrm{Zn}>\mathrm{Mn}>\mathrm{Cu}>\mathrm{Mo}>\mathrm{B}$. Others have pointed out that glyphosate causes lower availability of nutrients for uptake by plants (Franzen et al., 2003; Bott et al., 2008; Zobiole et al., 2010).

According to Eker et al. (2006), after glyphosate is absorbed by the plant, the uptake and transport of cationic micronutrients may be inhibited by the formation of poorly soluble glyphosate-metal complexes within plant tissues. Zobiole et al. (2010) reported that in different maturity group cultivars in different soil types, glyphosate reduced the shoot concentration of macro and micronutrients in GR soybeans. In the present work not only micronutrients but also macronutrients were affected by increasing glyphosate doses. Comparing the nutrient content in samples from nutrient solution, $\mathrm{P}, \mathrm{K}, \mathrm{S}$ and Mn were most absorbed by plants, which showed a positive linear increase 

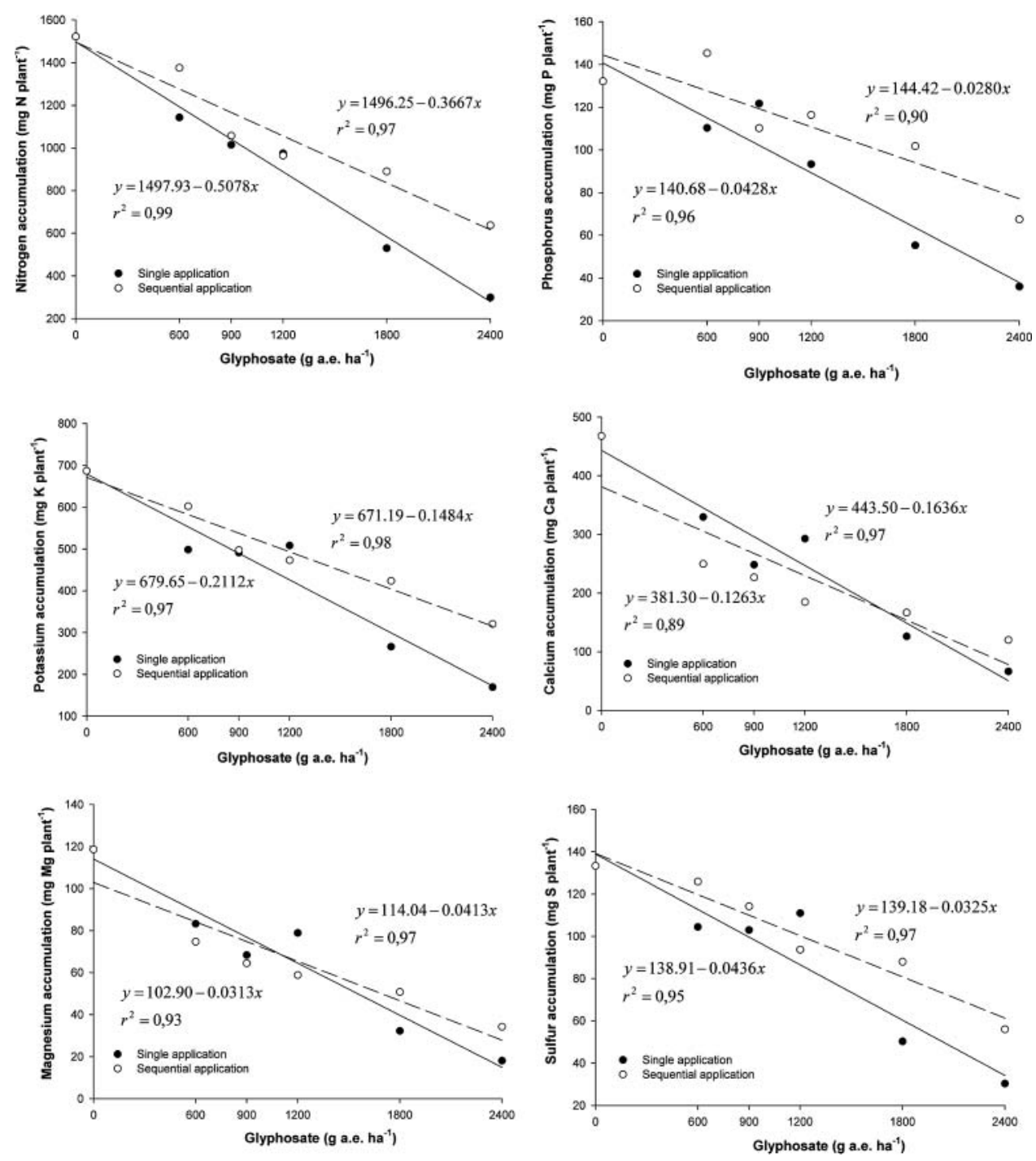

FIGURE 2 Macronutrient accumulation at R1 growth stage in GR soybean under increasing glyphosate doses in single (solid line) or sequential (dashed line) applications. Each point represents an average of four independent replicates.

with more intense glyphosate effects than $\mathrm{Ca}, \mathrm{Mg}, \mathrm{Zn}, \mathrm{Fe}$, and $\mathrm{Cu}$ (Figures 4 and 5).

All equations adjusted in Figures 2 and 3 demonstrated a slight but consistent difference between single and sequential glyphosate applications. As demonstrated by the angular coefficient for single applications, effects are usually more evident than those observed in sequential applications. Regarding the stronger effects of single glyphosate application, two aspects need to be considered: the younger plants and higher doses. The data presented 

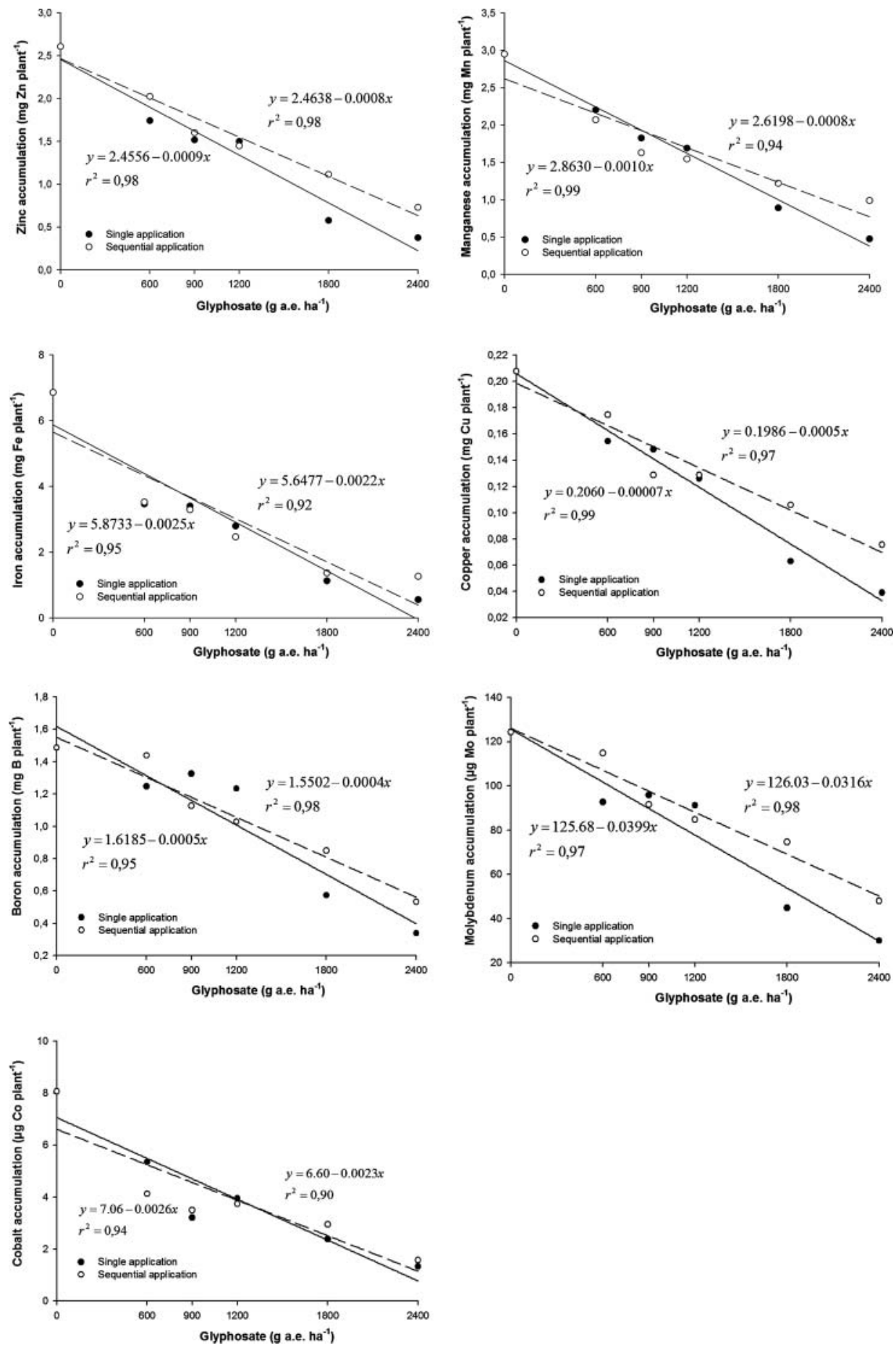

FIGURE 3 Micronutrient accumulation at R1 growth stage in GR soybean under increasing glyphosate doses in single (solid line) or sequential (dashed line) applications. Each point represents an average of four independent replicates. 

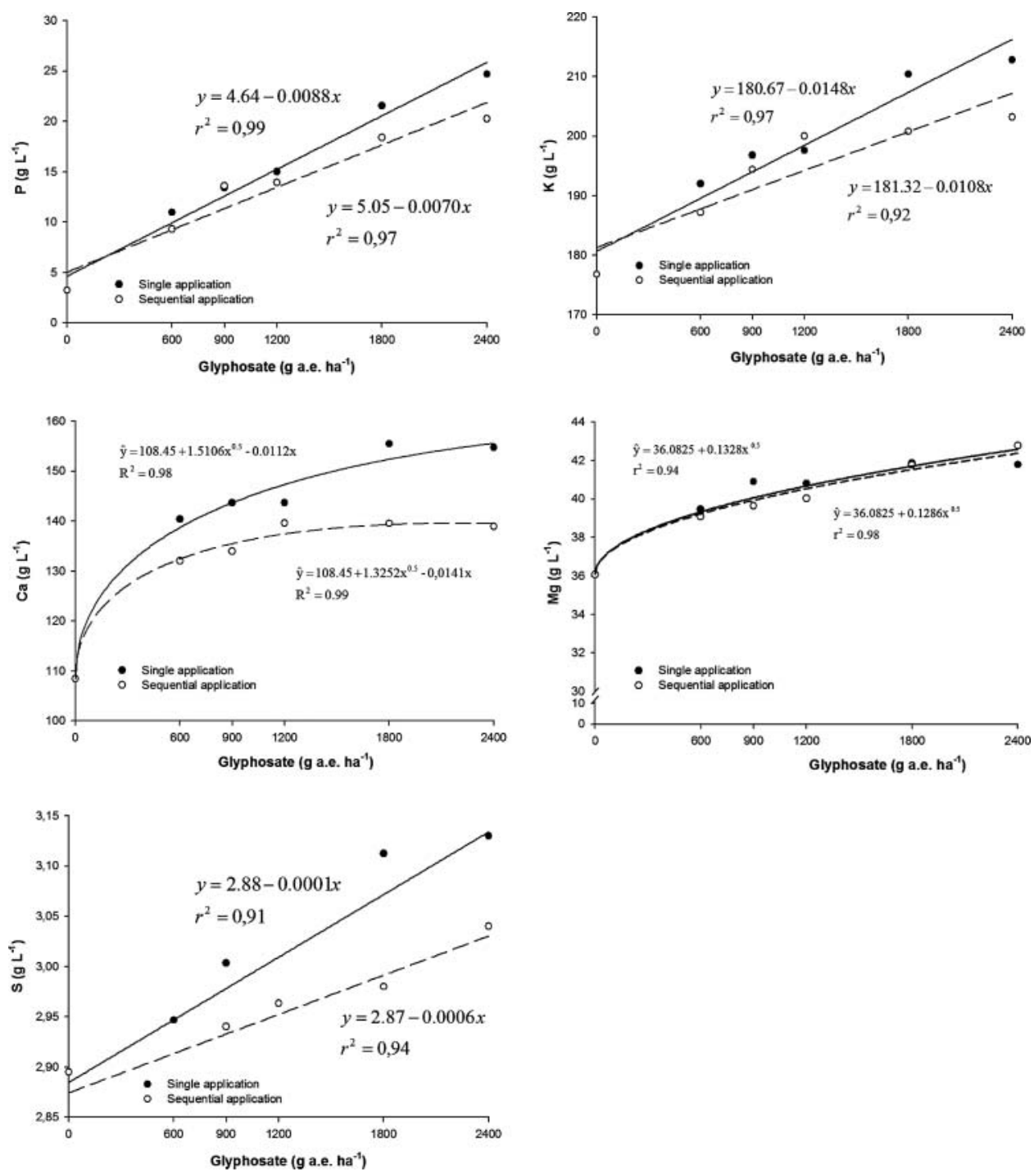

FIGURE 4 Concentration of macronutrients in a 50-mL sample of nutrient solution collected from pots at R1 growth stage in GR soybean under increasing glyphosate doses in single (solid line) or sequential (dashed line) applications. Each point represents an average of four independent replicates.

here, showed that younger plants (V4 growth stage) are more sensitive to glyphosate effects than plants receiving glyphosate at a later growth stage (V7). Because a single application contains the total dose, it differs from sequential application in which the same dose is fragmented $(50 \%-50 \%)$, thus, using a single application, the plant has less time to recover from the likely chelating effects of the higher glyphosate rate (Jaworski, 1972; Kabachnik et al., 1974; Madsen et al., 1978; Glass, 1984; Bromilow et al., 1993; Coutinho and Mazo, 2005; Eker et al., 2006; Zobiole et al., 2010). 

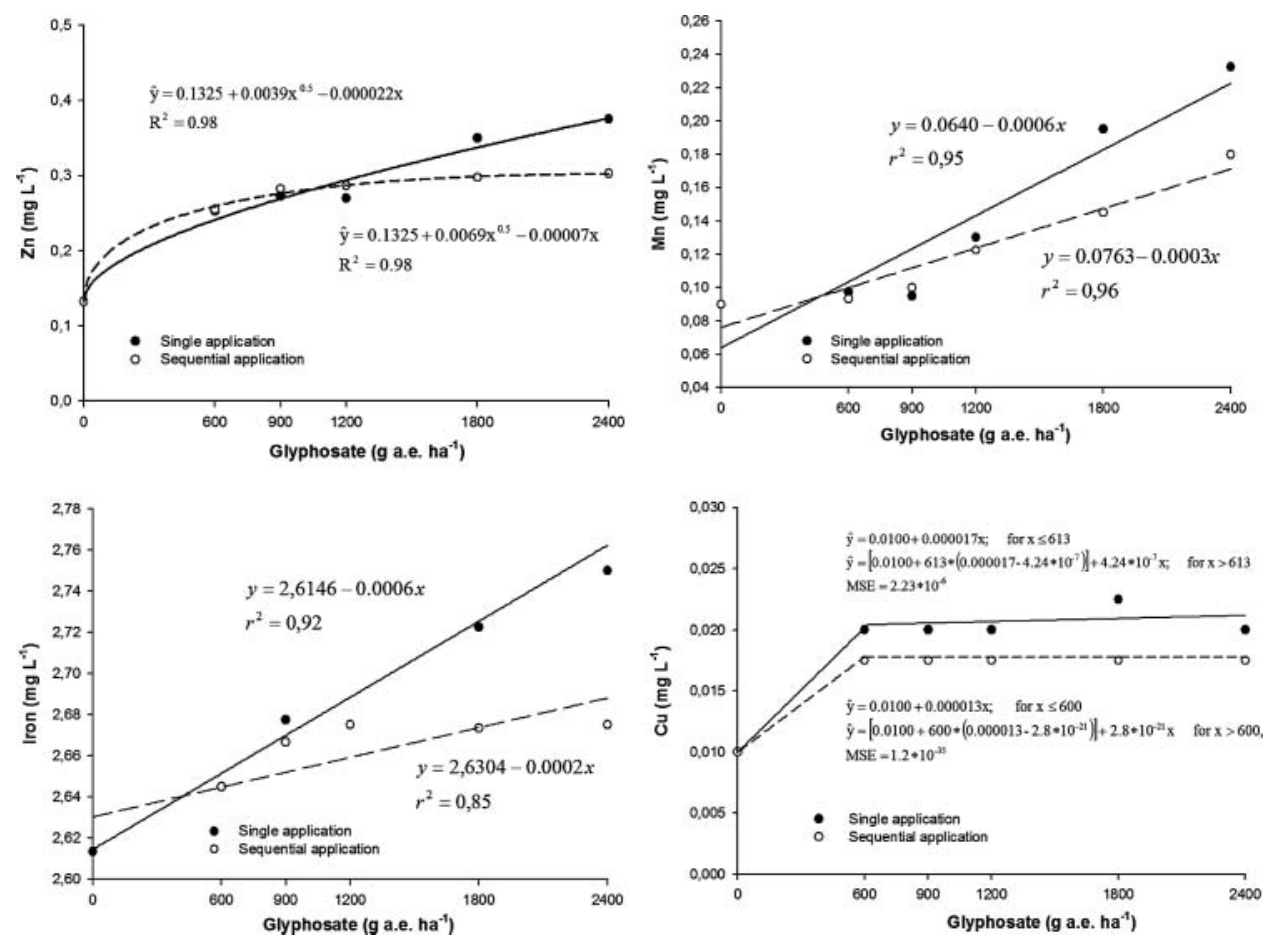

FIGURE 5 Concentration of micronutrients in a 50-mL sample of nutrient solution collected from pots at R1 growth stage in GR soybean under increasing glyphosate doses in single (solid line) or sequential (dashed line) applications. Each point represents an average of four independent replicates.

Since glyphosate forms insoluble metal complexes (Madsen et al., 1978; Glass, 1984; Coutinho and Mazo, 2005), the decrease in micronutrient accumulation could also affect the main function of chloroplast, i.e. photosynthesis, as evidenced by the severe reduction in photosynthetic parameters (Figure 1). Considering that chloroplasts are sensitive to Zn (Homann, 1967) and Mn (Thompson and Weier, 1962) deficiencies, the reduction of these essential microelements by increasing glyphosate doses in GR soybean (Figure 3), could explain the lower A, SPAD units, Fo and Fm in GR.

Data collected on the remaining macro and micronutrient concentrations in samples collected from the nutrient solutions provide evidence that plants subjected to glyphosate absorbed less nutrients (Figures 4 and 5). These results are inversely correlated to the nutrient accumulation in plants, i.e., plants that absorbed fewer nutrients might show higher concentration of nutrients in nutrient solution samples. Therefore, as in single application, the macro- and micronutrient accumulation was more affected than by sequential application (Figures 2 and 3); the nutrient concentrations in nutrient solution were consistently higher for single compared with sequential applications (Figures 4 and 5), due to lower nutrient uptake. 


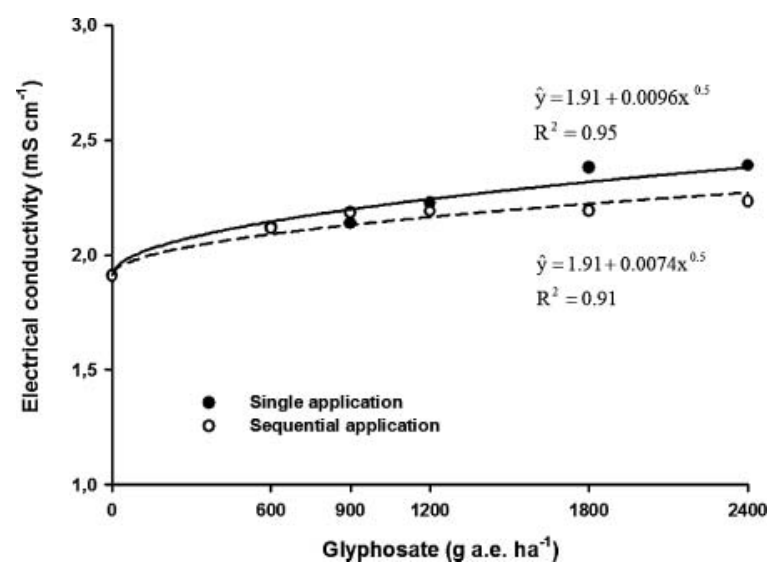

FIGURE 6 Electrical conductivity in a 50-mL sample of nutrient solution collected from pots at R1 growth stage in GR soybean under increasing glyphosate doses in single (solid line) or sequential (dashed line) applications. Each point represents an average of four independent replicates.

As electrical conductivity estimates the total amount of dissolved salts or ions in water, the results in Figure 6 show that increasing glyphosate doses also leads to higher nutrient concentrations remaining in the nutrient solution and, therefore higher electrical conductivity. Results of electrical
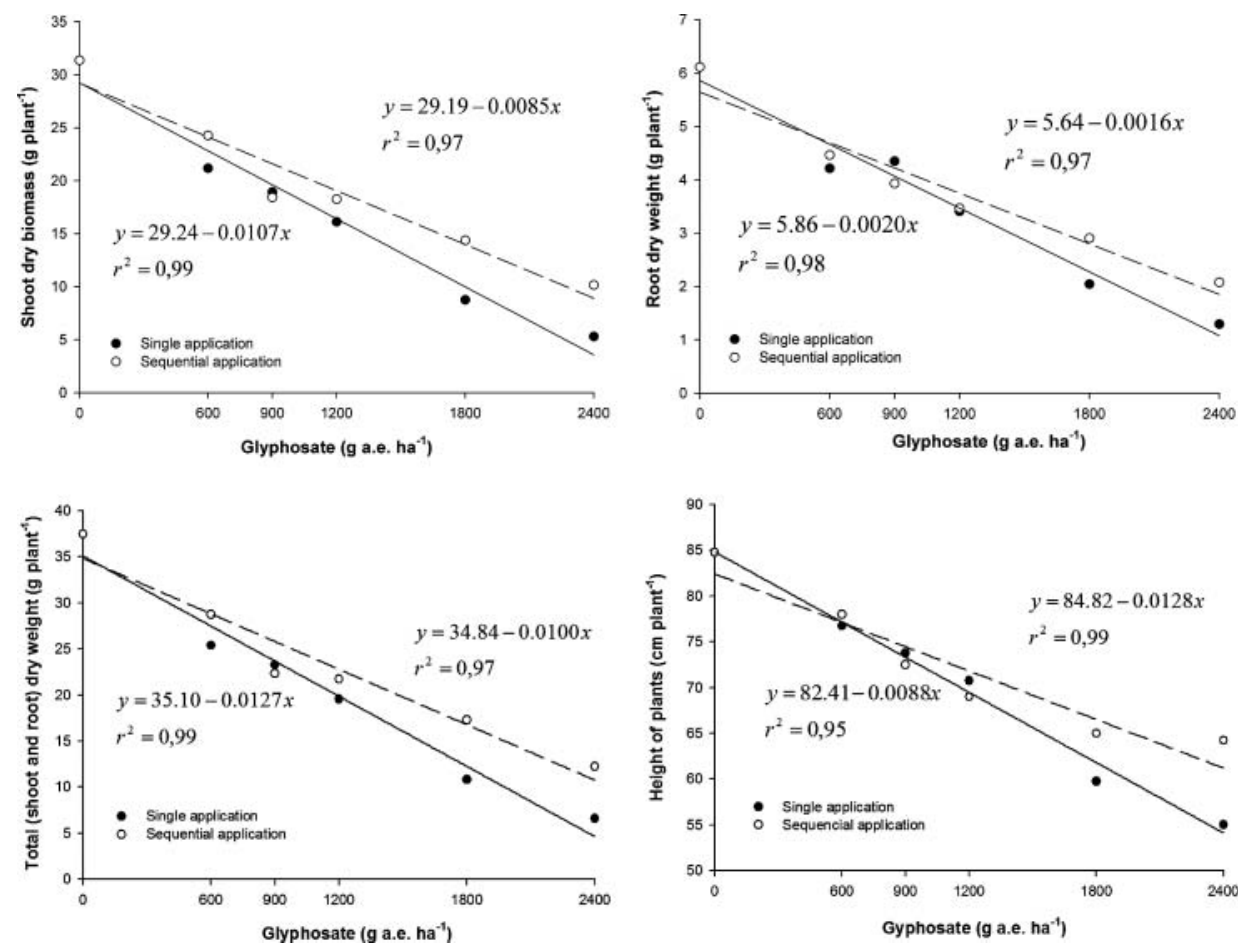

FIGURE 7 Shoot, root, total dry weight and height of plants at R1 growth stage in GR soybean under increasing glyphosate doses in single (solid line) or sequential (dashed line) applications. Each point represents an average of four independent replicates. 
conductivity agree with the previous discussion on single versus sequential application.

\section{Growth Parameters}

The total biomass production of soybean depends on energy supplied by photosynthesis for synthesizing carbon compounds (Shibles and Weber, 1965). Thus, decreases in A, SPAD units, Fo and Fm, and lower nutrient absorption and accumulation may have acted together to reduce plant height and biomass production in GR soybeans treated with glyphosate (Figure 7). Such effects in general were again more intense in plants under single application than those under sequential application.

Studies using glyphosate at $1200 \mathrm{~g}$ a.e. ha ${ }^{-1}$ (Zobiole et al., 2010), 1680 g a.e. ha ${ }^{-1}$ (Reddy et al., 2000) and $6300 \mathrm{~g}$ a.e. ha ${ }^{-1}$ (King et al., 2001) have shown reduced shoot and root dry weights of GR soybean under greenhouse conditions. In this research, shoot, root and consequently total biomass dry weight, were also reduced with glyphosate and these reductions were proportional to glyphosate dose.

\section{CONCLUSIONS}

Photosynthesis, nutrient accumulation and biomass production in GR soybean were strongly affected by glyphosate.

\section{ACKNOWLEDGEMENTS}

We thank the National Council for Scientific and Technology Development $(\mathrm{CNPq})$, for the scholarship and financial support. Trade names are used for clarity and do not represent endorsement by USDA-ARS or the State University of Maringá.

\section{REFERENCES}

Arregui, M. C., A. Lenardón, D. Sanchez, M. I. Maitr, R. Scotta, and S. Enrique. 2003. Monitoring glyphosate residues in transgenic glyphosate-resistant soybean. Pest Management Science 60: 163166.

Baker, W. H., and T. L. Thompson. 1992. Determination of total nitrogen in plant samples by Kjeldahl. In: Plant Analysis Reference Procedures for the Southern Region of the United State, Southern Cooperative Series Bulletin 368, ed. C. O. Plank, pp. 13-16. Athens: The Georgia Agricultural Experiment Station, University of Georgia.

Beale, S. I. 1978. $\delta$-Aminolevulinic acid in plants: Its biosynthesis, regulation and role in plastid development. Annual Review of Plant Physiology 29: 95-120.

Bott, S., T. Tesfamariam, H. Candan, I. Cakmak, V. Römheld, and G. Neumann. 2008. Glyphosate-induced impairment of plant growth and micronutrient status in glyphosate-resistant soybean (Glycine max L.). Plant and Soil 312: 185-194. 
Bromilow, R. H., K. Chamberlain, A. J. Tench, and R. H. Williams. 1993. Phloem translocation of strong acids: Glyphosate, substituted phosphonic, and sulfonic acids in Ricinus communis L. Pesticide Science 37: 39-47.

Coutinho, C. F. B., and L. H. Mazo. 2005. Metallic complex with glyphosate: A review. Química Nova 28: 1038-1045

Duke, S. O., A. M. Rimando, P. F. Pace, K. N. Reddy, and R. J. Smeda. 2003. Isoflavone, glyphosate, and aminomethylphosphonic acid levels in seeds of glyphosate-treated, glyphosate-resistant soybean. Journal of Agricultural and Food Chemistry 51: 340-344.

Eker, S., L. Ozturk, A. Yazici, B. Erenoglu, V. Römheld, and I. Cakmak. 2006. Foliar-applied glyphosate substantially reduced uptake and transport of iron and manganese in sunflower (Helianthus annuus L.) plants. Journal of Agricultural and Food Chemistry 54: 10019-10025.

Franzen, D. W., J. H. O'Barr, and R. K. Zollinger. 2003. Interaction of a foliar application of iron HEDTA and three postemergence broadleaf herbicides with soybeans stressed from chlorosis. Journal of Plant Nutritional 26: 2365-2374.

Glass, R. L. 1984. Metal complex formation by glyphosate. Journal of Agricultural and Food Chemistry 32: 1249-1253.

Gonzalez-Moro, B., M. Lacuesta, N. Iriberri, A. Muroz-Rueda, and C. Gonzalez-Murua. 1997. Comparative effects of PPT and AOA on photosynthesis and fluorescence chlorophyll parameters in Zea mays. Journal of Plant Physiology 151: 641-648.

Hoagland, D. R., and Arnon, D. J. 1950. The water culture method of growing plants without soil. Circular 347. Berkeley, CA: University of California.

Homann, P. E. 1967. Studies on the manganese of the chloroplast. Plant Physiology 42: 997-1007.

Ireland, C. R., M. P. Percival, and N. R. Baker. 1986. Modification of the induction of photosynthesis in wheat by glyphosate, an inhibitor of amino acid metabolism. Journal of Experimental Botany 37: 299-308.

Jaworski, E. G. 1972. Mode of action of N-phosphonomethyl-glycine: Inhibition of aromatic amino acid biosynthesis. Journal of Agricultural and Food Chemistry 20: 1195-1198.

Johal, G. S., and D. M. Huber. 2009. Glyphosate effects on diseases of plants. European Journal of Agronomy 31: 144-152.

Kabachnik, M. I., T. Y. Medved, N. M. Dyatolva, and M. V. Rudomino. 1974. Organophosphorus complexones. Russian Chemical Review 43: 733-744.

Kitchen, L. M., W. W. Witt, and C. E. Rieck. 1981a. Inhibition of chlorophyll accumulation by glyphosate. Weed Science 29: 513-516.

Kitchen, L. M., W. W. Witt, and C. E. Rieck. 1981b. Inhibition of $\delta$-aminolevulinic acid synthesis by glyphosate. Weed Science 29: 571-577.

King, C. A., L. C. Purcell, and E. D. Vories. 2001. Plant growth and nitrogenase activity of glyphosate-tolerant soybean in response to foliar glyphosate applications. Agronomy Journal 93: 79186.

Lee, T. T. 1981. Effects of glyphosate on synthesis and degradation of chlorophyll in soybean and tobacco cells. Weed Research 21: 161-164.

Lichtenthaler, H. K., and J. A. Miehé. 1997. Fluorescence imaging as a diagnostic tool for plant stress. Trends in Plant Science 2: 316-320.

Liu, F., M. N. Andersen, S. E. Jacobsen, and C. R. Jensen. 2005. Stomatal control and water use efficiency of soybean (Glycine $\max$ L. Merr.) during progressive soil drying. Environmental and Experimental Botany 54: 33-40.

Madsen, H. E. L., H. H. Christensen, and C. Gottlieb-Petersen. 1978. Stability constants of copper (II), zinc, manganese (II), calcium, and magnesium complexes of $N$-(phosphonomethyl)glycine (glyphosate). Acta Chemical Scandinavica 32: 79-83.

Maxwell, K., and G. N. Johnson. 2000. Chlorophyll fluorescence-A practical guide. Journal of Experimental Botany 51: 659-668.

Pinkard, E. A., V. Patel, and C. Mohammed. 2006. Chlorophyll and nitrogen determination for plantation-grown Eucaliptus nitens and E. glogulus using a non-destructive meter. Forest Ecology and Management 223: 211-217.

Pline, W. A., J. Wu, and K. K Hatzios. 1999. Effects of temperature and chemical additives on the response of transgenic herbicide-resistant soybeans to glufosinate and glyphosate applications. Pesticide Biochemistry and Physiology 65: 119-131. 
Procópio, S. O., J. B. Santos, A. A. Silva, C. A. Matinez, and R. C. Werlang. 2004. Physiological characteristics of soybean and common bean crops and three weed species. Planta Daninha 22: 211-216.

Reddy, K. N., R. E. Hoagland, and R. M. Zablotowicz. 2000. Effect of glyphosate on growth, chlorophyll, and nodulation in glyphosate-resistant and susceptible soybean (Glycine max) varieties. Journal of New Seeds 2: 37-52.

Reddy, K. N., A. M. Rimando, and S. O. Duke. 2004. Aminomethylphosphonic acid, a metabolite of glyphosate, causes injury in glyphosate-treated, glyphosate-resistant soybean. Journal of Agriculture and Food Chemistry 52: 5139-5143.

Reddy, K. N., and R. M. Zablotowicz. 2003. Glyphosate-resistant soybean response to various salts of glyphosate and glyphosate accumulation in soybean nodules. Weed Science 51: 496-502.

Richardson, A. D., S. P. Duigan, and G. P. Berlyn. 2002. An evaluation of noninvasive methods to estimate foliar chlorophyll content. New Phytologist 153: 185-194.

Shapiro, S. S., and M. B. Wilk. 1965. An analysis of variance test for normality. Biometrika 52: 591-611.

Shibles, R. M., and C. R. Weber. 1965. Leaf area, solar radiation interception, and dry matter production by various soybean planting patterns. Crop Science 6: 575-577.

Singh, B., Y. Singh, J. K. Ladha, K. F. Bronson, V. Balasubramanian, J. Singh, and C. S. Khind. 2002. Chlorophyll meter- and leaf color chart-based nitrogen management for rice and wheat in Northwestern India. Agronomy Journal 94: 821-89.

Sprankle, P., W. F. Meggitt, and D. Penner. 1975. Absorption, action, and translocation of glyphosate. Weed Science 23: 235-240.

Taiz, L., and E. Zeiger. 1998. Mineral Nutrition. In: Plant Physiology, eds. L. Taiz and E. Zeiger, pp. 111-114. Sunderland, MA: Sinauer Associates.

Thompson, W. W., and T. E. Weier. 1962. The fine structure of chloroplasts from mineral-deficient leaves of Phaseolus vulgaris. American Journal of Botany 49: 1047-1056.

Zablotowicz, R. M., and K. N. Reddy. 2007. Nitrogenase activity, nitrogen content, and yield responses to glyphosate in glyphosate-resistant soybean. Crop Protection 26: 370-376.

Zobiole, L. H. S., R. S. Oliveira Jr., D. M. Huber, J. Constantin, C. de Castro, F. A. de Oliveira, and A. Oliveira Jr. 2010. Glyphosate reduces shoot concentration of mineral nutrients in glyphosate-resistant soybeans. Plant and Soil 328: 57-69. 